\title{
ANALISIS KOEFISIEN ABSORPSI DARI MATERIAL BERBAHAN DASAR LIMBAH KAIN PERCA DAN PELEPAH PISANG
}

\author{
Patricia P. Noviandri ${ }^{1}$, Centaury Harjani ${ }^{2}$, Adindra M. K. Astuti ${ }^{3}$ \\ 1,3. Program Studi Arsitektur, Fakultas Arsitektur dan Desain, UKDW \\ 2. Program Studi Desain Produk, Fakultas Arsitektur dan Desain, UKDW \\ Email: patriciapahlevi@staff.ukdw.ac.id
}

\begin{abstract}
Abstrak
Penelitian awal terkait material limbah komposit dan alam telah dilakukan sebelumnya. Penelitian ini melanjutkan penelitian sebelumnya dengan metode pengujian yang lebih akurat yaitu menggunakan tabung impedansi. Sampel material yang dibuat pada penelitian ini merupakan sampel yang memiliki nilai NR (Noise Reduction) yang lebih besar pada penelitian sebelumnya. Sampel material yang dibuat sebanyak 4 sampel dengan variabel material pembentuk yang berbeda yaitu sampel komposit halus, komposit kasar, pelepah pisang, dan kombinasi (komposit halus dan pelepah pisang). Tiga sampel dicetak menggunakan tabung dengan diameter $30 \mathrm{~mm}$ dan tinggi 70 mm sedangkan 1 sampel kombinasi merupakan material yang digabung hingga mencapai ketinggan sebesar $50 \mathrm{~mm}$. Dari hasil pengujian, penambahan cavity mempengaruhi nilai koefisien absorpsi oleh sebab itu penggunaan material ini pada bangunan harus menggunakan rongga udara sehingga nilai koefisien absorpsinya meningkat. Sampel yang memiliki karakter sebagai material penyerap suara adalah material komposit halus, pelepah pisang, dan material kombinasi karena memiliki nilai koefisien absorpsi $(\alpha)$ lebih dari 0,30. Material kombinasi memiliki nilai NRC paling besar diantara sampel yang lain yaitu sebesar 0,57 .
\end{abstract}

Kata kunci: koefisien penyerapan, material, komposit, akustik, pelepah pisang.

\begin{abstract}
Title: Coefficient Absorpsi Analysis from Patchwork Material and Banana Midrib

Preliminary research related composite waste material and nature has done. This research continues the previous research with a more accurate testing method using impedance tubes. Material samples made in this study are samples that have a greater NR (Noise Reduction) value in previous studies. Material samples were made as many as 4 samples with different substance variables, namely fine composite samples, rough composites, banana midrib, and combinations (fine composites and banana midrib). Three samples were mold using a tube with a diameter of 30 $\mathrm{mm}$ and a height of $70 \mathrm{~mm}$ while one sample combination was a material that was combined to reach a height of $50 \mathrm{~mm}$. From the test results, the addition of cavity affects the absorption coefficient value, therefore the use of this material in buildings must use an air cavity so that the absorption coefficient value increases. Samples that have character as sound absorbing material are fine composite materials, banana fronds, and combination materials because they have an absorption coefficient value $(\alpha)$ of more than 0.30. The combination material has the highest NRC value among the other samples that is equal to 0.57 .
\end{abstract}

Keywords: absoption coefficient, material, composite, acoustic, banana midrib. 


\section{Pendahuluan}

Inovasi pemanfaatan limbah menjadi produk baru yang memiliki nilai lebih sangat penting pada masa ini. Limbah industri kecil yang meningkat tiap tahunnya membuat sampah yang dihasilkan di kota sangat banyak. Melalui penelitian sebelumnya, material komposit gipsum-kain dan material anyaman pelepah pisang memiliki nilai reduksi suara (Noise Reduction) yang tinggi diantara material lainnya (Astuti, Hidayat, Gedalya, \& Noviandri, 2019; Harjani \& Noviandri, 2018). Material akustik yang diteliti sebelumnya, belum memiliki perhitungan untuk spesifikasi material akustik berupa nilai koefisien absorpsi.

Material yang sebelumnya berupa material komposit limbah kain dan gipsum yang memiliki nilai paling tinggi dalam mengurangi suara. Selain itu, material serat pisang dengan anyaman berbentuk kipas juga memiliki nilai yang tinggi dalam mengurangi suara diantara jenis anyaman yang lainnya.

Penelitian ini merupakan tindak lanjut dari penelitian sebelumnya dengan melakukan pengujian koefisien absorpsi pada sampel tersebut. Permasalahan yang diangkat dalam penelitian ini adalah membandingkan nilai koefisien absorpsi yang ada dari beberapa sampel dan mengkategorikan spesifikasi material akustik tersebut. Spesifikasi material akustik yang berasal dari bahan limbah dapat dilihat berdasarkan nilai koefisien absorpsi. Manfaat yang dicapai yaitu produk material akustik dapat memiliki nilai koefisien absorpsi dengan standar ASTM (American Standard Testing and Material).
Material akustik digunakan sebagai pelapis permukaan interior di dalam sebuah ruang dengan fungsi akustik. Material akustik umumnya sebagai penyerap bunyi. Material akustik bersifat menunjang pengondisian akustik ruang dimana ruang lebih mendukung aspek suara yang diinginkan. Kriteria material akustik (Sutanto, 2015) antara lain :

a. Mengkondisikan akustik ruang dengan cara meningkatkan kejelasan wanted sound.

b. Material mampu mempengaruhi unwanted sound.

c. Material dapat diterapkan sebagai bidang interior.

d. Material mampu menyekat bunyi.

e. Material mampu meredam suara.

f. Material mampu mentransmisi bunyi.

Sifat dari material akustik antara lain ringan, berongga / porous / berserat, lunak, elastis, berpermukaan kasar absorbtif, dan transmitif (Sutanto, 2015).

Macam material akustik yaitu material absorpsi (absorber) dan material refleksi (reflektor). Material Absorpsi merupakan material yang berfungsi sebagai penyerap suara. Material absorbs ini memiliki prinsip sebagai berikut :

1. Material berpori

Material yang berpori bermanfaat dalam menyerap bunyi pada frekuensi lebih dari $1000 \mathrm{~Hz}$. Hal ini disebabkan karena pori-porinya yang kecil sesuai dengan besaran Panjang gelombang bunyi yang datang.

2. Ketebalan

Ketebalan material penyerap suara memberikan dampak pada efisiensi material tersebut menjalankan fungsinya. Semakin tebal material penyerap maka 
dapat lebih banyak menyerap energi suara pada frekuensi rendah.

3. Lapisan luar

Penambahan lapisan luar seperti lembaran kain maupun papan membuat kekuatan penyerapan semakin meningkat.

Material yang menyerap bunyi merupakan material yang mampu mengurangi energi bunyi dengan cara mengubahnya menjadi energi panas. Efisiensi penyerapan bunyi suatu bahan pada frekuensi tertentu dinyatakan oleh koefisien penyerapan (absorpsi) bunyi. Karakter material absorpsi tidak berubah, koefisien absorpsi suatu material dapat berubah menyesuaikan dengan frekuensi bunyi datang.

Karakter material penyerap bunyi yaitu bunyi datang yang diserap atau tidak dipantulkan oleh permukaan. Koefisien absorpsi bunyi adalah angka yang menunjukkan jumlah / proporsi dari keseluruhan energi bunyi yang datang dan mampu diserap oleh material tersebut (Mediastika, 2005). Koefisien absorpsi dinyatakan dengan $\alpha$. Nilai $\alpha$ antara 0 dan 1 didasarkan pada presentase penyerapan bunyi oleh bahan pada frekuensi tertentu. Frekuensi standar yang diperoleh 125 , 250, 500, 1000, 2000, dan $4000 \mathrm{~Hz}$. Nilai $\alpha$ yang semakin mendekati 1 maka material tersebut mampu menyerap suara (Hayat, Syakbaniah, \& Darvina, 2013).

Refleksi adalah pemantulan bunyi suatu objek penghalang / bidang batas disebabkan oleh karakteristik penghalang yang memungkinkan terjadinya pemantulan (Mediastika, 2005). Material refleksi berarti material yang mampu memantulkan suara. Semakin keras, licin, dan homogen suatu bidang maka semakin besar tingkat pemantulan yang dihasilkan.

Koefisien refleksi adalah parameter yang mendeskripsikan berapa besar gelombang elektromagnetik yang berhenti memantul dalam media transmisi (Zhang, Krooswyk, \& Ou, 2015).

\section{Metode Penelitian}

\section{Metode Pembuatan Sampel}

Pada sampel komposit gipsum dan kain dibuat menjadi 2 sampel yaitu sampel dengan kain drill dan denim halus dan kain drill dan denim kasar. Sampel ini dicetak menggunakan pipa pvc dengan diameter $30 \mathrm{~mm}$ dan tinggi $70 \mathrm{~mm}$.

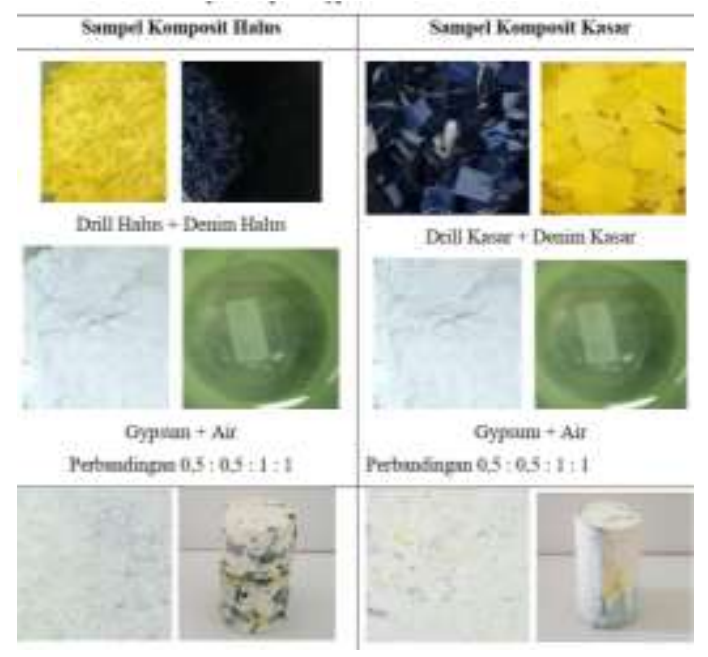

Gambar 1. Proses pengolahan sampel komposit (campuran gypsum dan kain) sumber : Penulis, 2019

Pelepah pisang yang digunakan merupakan pelepah pisang yang sudah kering. Pelepah pisang dianyam terlebih dahulu seperti bentuk kipas sate yang memiliki karakter yang tebal (4,2 $\mathrm{mm})$, berongga, dan berserat. Pelepah pisang yang sudah di anyaman kemudian di gulung hingga memiliki 
diameter $30 \mathrm{~mm}$ dengan ketinggian 70 $\mathrm{mm}$.

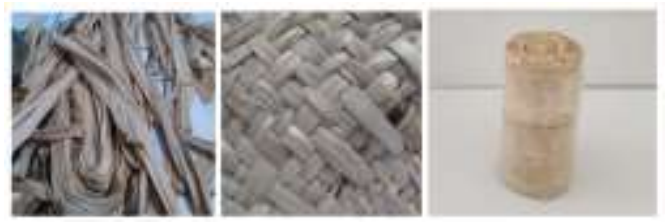

Gambar 2. Proses pengolahan pelepah pisang menjadi sampel material akustik sumber : Penulis, 2019

Sampel campuran yang dimaksudkan adalah sampel kombinasi yang terdiri dari sampel komposit dan sampel pelepah pisang. Sampel ini merupakan contoh sampel dari material berlapis.

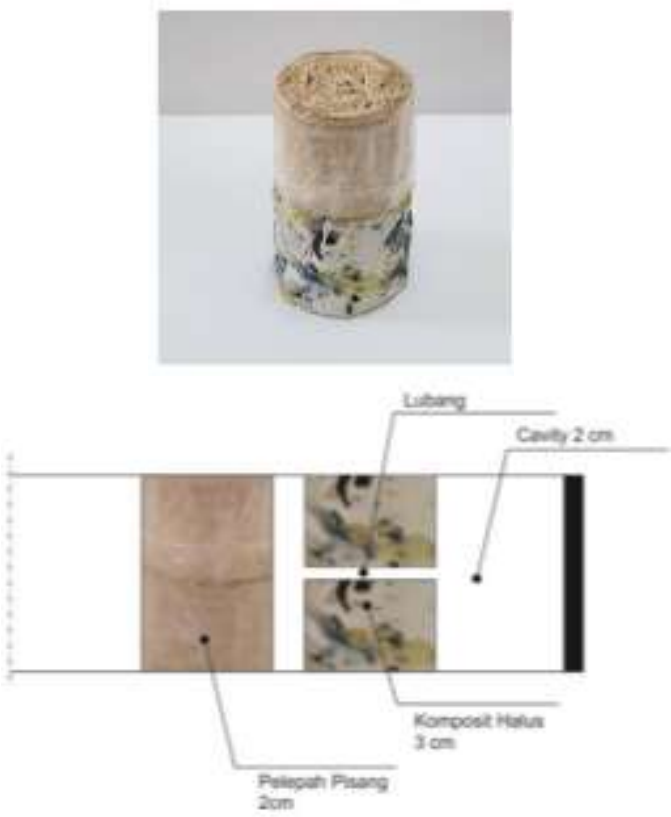

Gambar 3. Sampel campuran (komposit dan pelepah pisang) sumber : Penulis, 2019

\section{Metode Pengujian Koefisien Serapan}

Peralatan yang digunakan untuk mengukur koefisien serap bahan adalah tabung impedansi dengan sampel berdiameter $30 \mathrm{~mm}$. Pengujian dilakukan dengan bantuan mitra Iarg Laboratorium Riset Akustik, Fakultas MIPA Universitas Sebelas Maret
(UNS). Diagram rangkaian alatnya seperti ditunjukkan gambar 4.

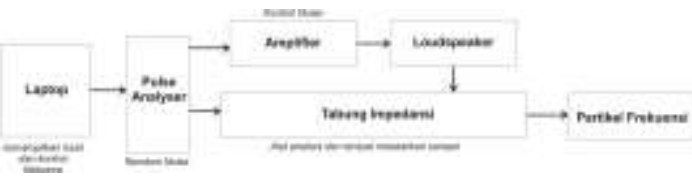

Gambar 4. Metode pengukuran koefisien absorpsi dengan tabung impedansi Sumber : Penulis, 2019

\section{Hasil dan Pembahasan}

\section{Koefisien Absorpsi Material Komposit}

Sampel komposit halus terdiri dari kain drill dan kain denim dicampur dengan gipsum. Sampel ini memiliki karakter permukaan keras dan tidak rata karena adanya kain-kain pengisi yang terlihat dibagian luar sampel. Kain-kain yang halus tercampur secara merata dengan gipsum dan air.

Dari gambar 5 dapat dilihat bahwa sampel komposit halus memiliki rentang nilai koefisien absorpsi antara 0,08 sampai 0,40 . Nilai koefisien absorpsi terendah pada frekuensi 128 Hz. Koefisien absorpsi material ini optimal pada frekuensi $504 \mathrm{~Hz}, 1000$ $\mathrm{Hz}, 4000 \mathrm{~Hz}$, dan $5000 \mathrm{~Hz}$. Nilai koefisien absorpsi yang masih dibawah 0,50 ini berarti material ini masih memiliki karakter sebagai reflektor yang cukup besar (koefisien refleksi diatas 0,70$)$.

Perbedaan terjadi pada frekuensi 128 $\mathrm{Hz}$ sampai dengan $2000 \mathrm{~Hz}$ ketika sampel diberikan tambahan cavity dari dinding tabung impedansi. Pada frekuensi $128 \mathrm{~Hz}, 256 \mathrm{~Hz}$, dan 2000 $\mathrm{Hz}$, sampel mengalami kenaikan kapabilitas dalam menyerap suara yang cukup besar. Penurunan kemampuan material dalam menyerap suara. 
Sampel komposit kasar memiliki karakter permukaan keras. Permukaan sampel ini sangat rata hal ini disebabkan jenis kain yang digunakan dalam campuran ini adalah kain yang ukurannya besar (kurang lebih sisi terpanjang $50 \mathrm{~mm}$ ). Kain ini tidak dapat tercampur dengan sempurna melainkan menjadi lembaran-lembaran pemisah diantara bahan gipsum.

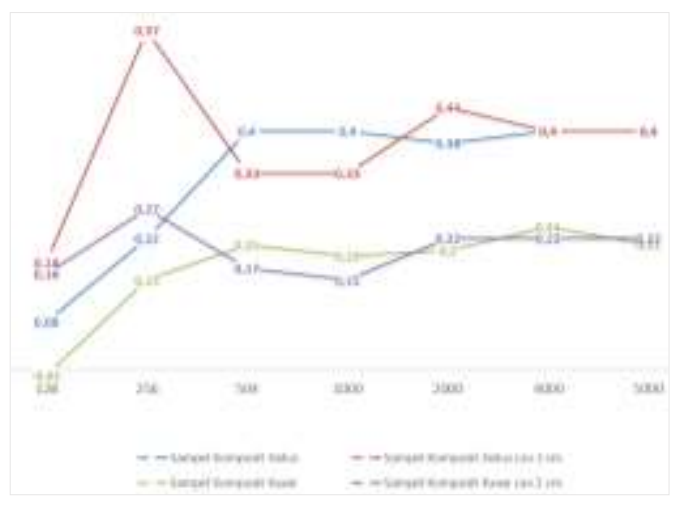

Gambar 5. Grafik koefisien absorpsi material komposit

Sumber : Analisis, 2019

Nilai koefisien absorpsi pada material komposit kasar ini rata-rata lebih kecil dibandingkan nilai koefisien absorpsi sampel sebelumnya (komposit halus). Nilai dari koefisien absorpsi material komposit kasar ini pada rentang 0,01 sampai dengan 0,24.

Nilai-nilai yang ada dari analisis menggunakan tabung impedansi inilah memperlihatkan karakter material komposit kasar sebagai material reflektor. Material reflektor yang berarti material ini lebih mampu memantulkan suara. Nilai koefisien absorpsi yang cenderung tinggi dan meningkat ketika dilakukan analisis dengan menambahkan cavity. Material ini efektif sebagai reflektor untuk frekuensi $128 \mathrm{~Hz}$ sampai $5000 \mathrm{~Hz}$.

\section{Koefisien Absorpsi Material Pelepah Pisang}

Sampel berbahan dasar pelepah pisang memiliki permukaan berpori dan lunak. Sampel pelepah pisang ini dibuat dengan cara menganyam terlebih dahulu dan kemudian di gulung hingga padat. Penganyaman dilakukan seperti pola kipas sate. Anyaman tidak terlihat saat sampel telah digulung. Anyaman yang dipilih merupakan anyaman yang diindikasikan memiliki NR yang besar pada penelitian sebelumnya (Astuti et al., 2019). Anyaman kipas sate memiliki kerapatan yang lebih kencang dan berpori yang lebih banyak. Selain itu, sampel anyaman pelepah pisang memiliki ketebalan hingga $70 \mathrm{~cm}$ sehingga memiliki rongga yang banyak yang mempengaruhi penyerapan suaranya (Nabila \& Mahyudin, 2020). Secara fisik, sampel ini sudah mengindikasikan memiliki koefisien absorpsi yang tinggi.

Sampel Pelepah Pisang memiliki kemampuan dalam menyerap suara lebih baik dibanding kedua sampel sebelumnya (kombinasi halus dan kombinasi kasar) yang dapat dilihat di gambar 6. Rentang nilai koefisien absorpsi material yaitu 0,12 sampai 0,77. Koefisien absorpsi bahan tertinggi pada frekuensi $4000 \mathrm{~Hz}$ dan $5000 \mathrm{~Hz}$. 


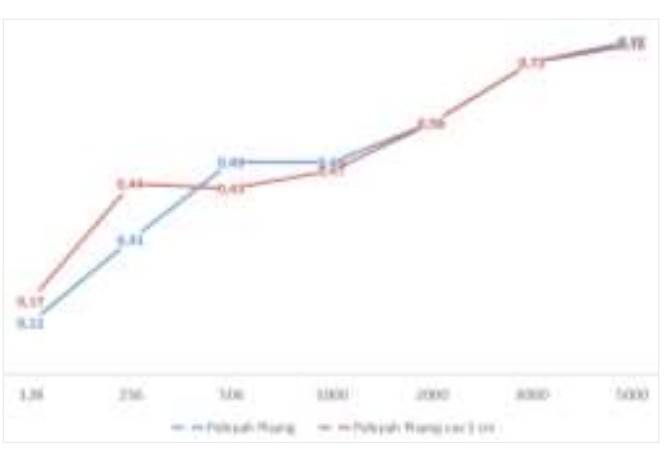

Gambar 6. Grafik koefisien absorpsi material pelepah pisang

Sumber : Analisis, 2019

Hasil pengujian sampel dengan penambahan cavity mendapatkan hasil yang tidak jauh berbeda dengan pengukuran sebelumnya. Sehingga dapat disimpulkan bahwa pada material pelepah pisang cavity tidak memiliki pengaruh terhadap performa sebagai bahan penyerap suara. Hal ini disebabkan didalam material pelepah pisang telah memiliki udara karena bentuknya yang berpori.

Material pelepah pisang lebih efektif dalam menyerap suara pada frekuensi $504 \mathrm{~Hz}$ sampai dengan $5000 \mathrm{~Hz}$. Material ini dapat disebutkan sebagai material absorber yang efektif dalam menangani frekuensi sedang hingga tinggi. Material yang berpori akan lebih mampu menyerap frekuensi sedang dan tinggi.

\section{Koefisien Absorpsi Material Kombinasi}

Material kombinasi terdiri dari dua material penyerap suara yang telah diteliti sebelumnya antara lain komposit halus dan pelepah pisang. Penggabungan material ini dilakukan dengan pemotongan masing-masing material. Material komposit halus dipotong menjadi tebal $30 \mathrm{~mm}$ dan material pelepah pisang dipotong menjadi $20 \mathrm{~mm}$.

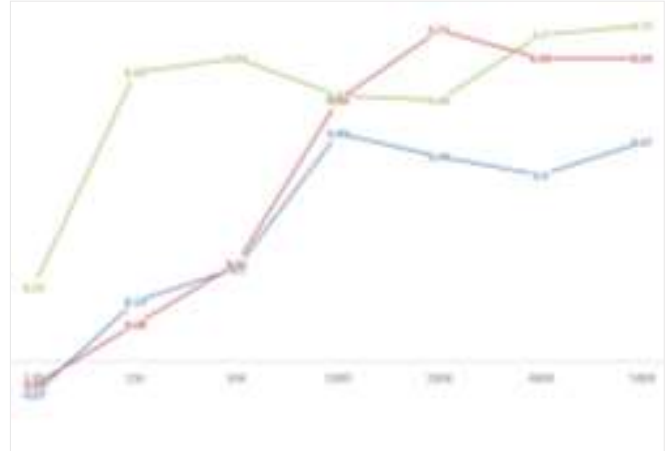

Gambar 7. Grafik koefisien absorpsi material kombinasi

Sumber : Analisis, 2019

Hasil dari material kombinasi ini yaitu material ini diindikasikan mampu menjadi material absorpsi pada frekuensi rendah hingga tinggi. Walaupun pada frekuensi $128 \mathrm{~Hz}$ nilai koefisien absorpsi tidak terlalu besar $(\alpha=0,16)$. Dari gambar 7 , dapat dilihat perbandingan nilai koefisien absorpsi tiap bahan yang telah dipotong dan sebelum digabungkan yang keseluruhannya mendapatkan nilai yang kurang dari 0,50 .

Rentang nilai koefisien absorpsi dengan kombinasi yaitu 0,16 sampai dengan 0,72. Nilai koefisien absorpsi paling tinggi pada frekuensi $5000 \mathrm{~Hz}$ sebesar 0.72 . Perpaduan dua material ini membuat peningkatan yang signifikan dalam pengolahan material.

Dari hasil pengujian tersebut, penambahan cavity mempengaruhi nilai koefisien absorpsi. Sampel mengalami kenaikan koefisien absorpsi maksimal sebesar 0,3 pada satu frekuensi. Oleh sebab itu, perbandingan antar sampel (tabel 1) diambil nilai koefisien absorpsi yang menggunakan cavity. Aplikasi adanya cavity ini pada bangunan yaitu memberikan rongga udara pada saat pemasangan. 
Tabel 1. Perbandingan antar sampel

\begin{tabular}{|c|c|c|c|c|}
\hline \multirow{2}{*}{ 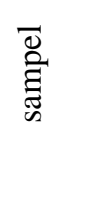 } & & 8,2 & & 5 \\
\hline & komposit kasar & komposit halus & pelepah pisang & Kombi-nasi \\
\hline $\mathrm{d}$ & $30 \mathrm{~mm}$ & $30 \mathrm{~mm}$ & $30 \mathrm{~mm}$ & $30 \mathrm{~mm}$ \\
\hline $\mathrm{h}$ & $70 \mathrm{~mm}$ & $70 \mathrm{~mm}$ & $70 \mathrm{~mm}$ & $50 \mathrm{~mm}$ \\
\hline cav & $20 \mathrm{~mm}$ & $20 \mathrm{~mm}$ & $20 \mathrm{~mm}$ & $20 \mathrm{~mm}$ \\
\hline$\alpha_{\min }$ & 0,16 & 0,18 & 0,17 & 0,16 \\
\hline$\alpha_{\max }$ & 0,22 & 0,57 & 0,76 & 0,72 \\
\hline NRC & 0,20 & 0,37 & 0,51 & 0,57 \\
\hline$f_{\text {efextif }}$ & - & $256-5000 \mathrm{~Hz}$ & $256-5000 \mathrm{~Hz}$ & $256-5000 \mathrm{~Hz}$ \\
\hline & Reflektor & absorber & absorber & absorber \\
\hline
\end{tabular}

Catatan :

NRC $($ Noise Reduction Coefficient $)=$ Rata-rata nilai koefisien absorbsi

$\mathrm{f}_{\text {efektif }}=$ frekuensi efektif dimana nilai $\alpha>0,30$

Sumber : Analisis, 2019

Dari keempat sampel yang diuji menggunakan tabung impedansi, dapat dilihat bahwa satu dari sampel tersebut memiliki karakter sebagai material reflektor. Material yang memiliki koefisien kurang dari 0,30 dapat dianggap tidak memiliki kualitas sebagai bahan penyerap yang baik (Doelle, 1972). Ketiga sampel yang lain memiliki karakter material penyerap suara. Namun, sampel material kombinasi memiliki nilai NRC (Noise Reduction Coefficient) yang lebih besar. Oleh sebab itu, material kombinasi dapat diidentifikasi sebagai material paling efektif dalam menyerap suara.

\section{Kesimpulan}

Komposit halus dan pelepah pisang memiliki kemampuan sebagai absorber pada frekuensi sedang sampai tinggi. Percobaan menggunakan material kombinasi memberikan gambaran metode penambahan nilai koefisien absorpsi dengan cara penggabungan 2

material absorber. Material kombinasi ini memiliki nilai koefisien absorpsi yang cukup baik yaitu 0,56 sampai dengan 0,72 pada frekuensi $256 \mathrm{~Hz}$ hingga $5000 \mathrm{~Hz}$.

Material kombinasi dapat dikembangkan lagi menjadi material akustik berupa resonator berongga maupun diffuser. Hal ini disebabkan kedua material tersebut memiliki dua karakteristik yang berbeda yaitu padat dan lunak. Namun, perlu adanya pengolahan material yang memiliki bentuk lain dan telah diketahui berat dari material akustik tersebut. Penelitian selanjutnya akan meningkatkan kualitas material kombinasi untuk dapat dijadikan produk industri.

\section{Ucapan Terima Kasih}

Penulis mengucapkan terima kasih pada Bapak Iwan Yahya dan tim dari Laboratorium Riset Akustik (iARG) jurusan Fisika FMIPA UNS yang telah 
membantu peneliti dalam analisis material.

\section{Daftar Pustaka}

Astuti, A. M. K., Hidayat, D., Gedalya, V. F., \& Noviandri, P. P. (2019). Pelepah Pisang Sebagai Alternatif Mterial Dalam Mengurangi Suara. SMART (Seminar on Architecture Research \& Technology), 4 (URBAN + LAB: Konsep, Prinsip dan Strategi Rancang Ruang Hidup di Kawasan Perkotaan), 31-40. Yogyakarta: Fakultas Arsitektur dan Desain Universitas Kristen Duta Wacana Yogyakarta. https://doi.org/10.21460/smart.v4i 1

Doelle, L. L. (1972). Environmental acoustics. New York: McGrawHill.

Harjani, C. \& Noviandri, P. P. (2018). Sound Proofing Panel Made from Patchwork and Gypsum as a Green Material Innovation. SMART (Seminar on Architecture Research \& Technology), 3, 111118. Yogyakarta: Fakultas Arsitektur dan Desain Universitas Kristen Duta Wacana Yogyakarta. Hayat, W., Syakbaniah, \& Darvina, Y. (2013). Pengaruh Kerapatan terhadap Koefisien Absorbsi Bunyi Papan Partikel Serat Daun Nenas. Jurnal Pillar of Physycs, 1(April), 44-51.

Mediastika, C. E. (2005). Akustika Bangunan. Jakarta: Erlangga.

Nabila, N., \& Mahyudin, A. (2020). Pengaruh Ketebalan Pelepah Pisang terhadap Koefisien Absorpsi Material Akustik. Jurnal Fisika Unand, 9(2), 244-249.

Sutanto, H. (2015). Prinsip-Prinsip Akustik dalam Arsitektur (1st ed.). Yogyakarta: PT. Kanisius.

Zhang, H., Krooswyk, S., \& Ou, J.
(2015). Digital Design Design of High Speed Interconnects and Signaling. USA: Elsevier B.V. 